\title{
The role of two non-indigenous serpulid tube worms in shaping artificial hard substrata communities: case study of a fish farm in the central Mediterranean Sea
}

\author{
M. Cristina Mangano ${ }^{1,2}$, Francesca Ape $^{3}$, Simone Mirto ${ }^{3, *}$ \\ ${ }^{1}$ Dipartimento di Scienze della Terra e del Mare, Università degli Studi di Palermo, Viale delle Scienze Ed. 16, \\ 90128 Palermo, Italy \\ ${ }^{2}$ School of Ocean Sciences, Bangor University, 328 Westbury Mount, Menai Bridge, Anglesey LL59 5AB, UK \\ ${ }^{3}$ Istituto per lo studio degli impatti Antropici e Sostenibilità in ambiente marino (IAS-CNR), Via G. da Verrazzano 17, \\ 91014 Castellammare del Golfo, TP, Italy
}

\begin{abstract}
Understanding the spread and establishment of non-indigenous species (NIS) is one of the primary areas of focus in bioinvasion science and is essential for generating appropriate management strategies in aquaculture. Here we investigated the role of 2 non-indigenous serpulid tube worms (Hydroides elegans and H. dirampha) in shaping the hard substrata communities around a fish farm in the Strait of Sicily over 1 yr (June 2014-June 2015), at 3 mo intervals (September and December 2014, March and June 2015). The mean density values of serpulids were significantly different at each sampling time. The density of serpulids on submerged panels showed a peak in spring (March 2015, after $9 \mathrm{mo}$ ) and decreased drastically in summer (June 2015). Hydroides shaped the entire associated macrobenthic community, which showed the highest density in the first month of observations. The lowest density was recorded in proximity to the highest density of serpulids. Margalef's species richness of the associated macrofaunal community peaked at the end of monitoring (summer). Our results will add new insights into the role of aquaculture as a vector and pathway for NIS.
\end{abstract}

KEY WORDS: Non-indigenous species - Annelida - Serpulidae - Macrofouling - Pathway · Aquaculture cages

\section{INTRODUCTION}

Non-indigenous species (NIS) are recognised as one of the major threats affecting biodiversity worldwide (Didham et al. 2007, Molnar et al. 2008) and since the last decade have become one of the focus areas of bioinvasion science (Pyšek \& Richardson 2010, Vilà et al. 2011, Kumschick et al. 2015). NIS abundance and diversity vary on both regional and global scales, in both terrestrial and aquatic environments (Molnar et al. 2008, Byers et al. 2015, van Kleunen et al. 2015, Fletcher et al. 2016), according to a complex combination of differences in life histories

*Corresponding author: simone.mirto@cnr.it and biological traits, timing and type of transport vectors, and abiotic and interactive biotic factors in the recipient environment (Wonham \& Carlton 2005, Katsanevakis et al. 2014, Ojaveer et al. 2014, Hulme et al. 2015, Cardeccia et al. 2018, Sarà et al. 2018c). Invasions can generate further cascading effects, such as the alteration of local inter- and intraspecific relationships within native species (Shea \& Chesson 2002, Wallentinus \& Nyberg 2007) and the alteration of resource dynamics, which facilitate NIS spreading and further enhance the effects on biodiversity at a local scale (Meiners et al. 2001, Stachowicz et al. 2002, Yurkonis et al. 2005).

() The authors 2019. Open Access under Creative Commons by Attribution Licence. Use, distribution and reproduction are unrestricted. Authors and original publication must be credited. 
Although some authors have recently focused on the study of seasonal NIS succession and macrofouling community development (Lezzi et al. 2018, Martell et al. 2018), to date, the facilitation processes that regulate the spatial and temporal settlement, growth, population size and features of NIS are poorly known, especially in a Mediterranean context (Galil et al. 2018). Within fouling communities, more attention has been paid to sessile NIS, including a various array of solitary and colonial marine invertebrates (e.g. ascidians, bryozoans, bivalve molluscs, tube-building polychaete worms, sponges, barnacles and sea anemones; Wallentinus \& Nyberg 2007, Lezzi et al. 2018, Sarà et al. 2018a). These organisms not only shape local metabolic and trophic interactions, by altering the physical or biological environment in the system, they can exert a strong habitat-modifying effect, making it more suitable for some species and less so for others (Stachowicz et al. 2002, Floerl et al. 2004, Sarà et al. 2018a,b). NIS habitat modifications might have a pronounced ecosystem impact and may cause changes in ecosystem goods and services (Wallentinus \& Nyberg 2007, Sarà et al. 2018b). To disentangle the set of factors that can determine larval settlement and intra- or interspecific interactions along successive stages of colonisation (from recruitment to the maximum density step), it may be crucial to have an in-depth understanding of sessile NIS distribution and density (Bramanti et al. 2003). Such information is valuable when setting up modelling exercises (Sarà et al. 2018c) or when shaping new regional and cross-border NIS management strategies and plans and, more specifically, to facilitate the evaluation of risks and impacts associated with future spreading (Ojaveer et al. 2015).

A call for more efforts in reporting and monitoring NIS species is still widely advocated from many sides worldwide and from one of the most demanding European legislative instruments, the Marine Strategy Framework Directive (e.g. MSFD Descriptor 2; ICES 2016, Zenetos et al. 2017, Galil et al. 2018). To effectively deal with risk and impact evaluations on local biodiversity and ecosystem functioning, scientists, legislators, stakeholders and policy makers have pointed out the need for (1) an improved NIS database, (2) integrated checklists and databases based on geo-referenced occurrence and (3) proactive monitoring programmes and modelling exercises (Molnar et al. 2008, Hewitt et al. 2009, Ojaveer et al. 2014, Sarà et al. 2018a,b). To date, the MSFD (EC 2008), among other descriptors, includes the 'impacts of non-indigenous invasive species at the level of species, habitats and ecosystems', acknowl- edging the critical role of vectors in biological invasions and considering the importance of managing the pathways of invasion to guarantee Good Environmental Status. This becomes particularly compelling in the Mediterranean Sea, a melting pot of bioinvasions showing the highest number of records of species introduced compared with other European seas (Galil et al. 2014).

In this regard, the aquaculture industry has been recognised as one of the main pathways of NIS introduction to Europe (Fernandez-Gonzalez \& SanchezJerez 2014). Furthermore, the hard substrata of aquaculture plants (e.g. nets, mooring structures and polyvinyl finfish cage collars) provide novel suitable habitat for colonisation and settlement of a wide variety of marine organisms (Sarà et al. 2007). Many NIS find easy housing among the encrusting benthic faunal communities, hereafter called biofouling or macrofouling (Molnar et al. 2008, Nunes et al. 2014, Floerl et al. 2016, Katsanevakis et al. 2016). Once again, little is known about the mechanisms that regulate and promote the distribution of NIS across these artificial surfaces. Another topic that remains poorly investigated is the temporal aspect of such colonisations, in particular the long-term consequences of NIS introductions that remain unknown (Ramsay et al. 2008, Rius et al. 2011). The study of the temporal dynamics of fouling communities could help researchers to understand whether they are more or less permanent and whether they can act as a source that can inoculate natural communities in the surrounding area.

Here we planned an extensive 1 yr manipulative experiment around aquaculture cages to provide quantitative and qualitative data on the occurrence and density of serpulid species. Serpulids constitute one of the most important groups in the marine fouling biota (Koçak et al. 1999, Çinar 2006), and our data will offer useful insights into the investigation of the potential role of an aquaculture plant in becoming a NIS hotspot. Our target species were 2 serpulid tubeworm foulers, Hydroides elegans (Haswell, 1883) and H. dirampha (Mörch, 1863), considered invasive marine aliens in the Mediterranean Sea (Zenetos et al. 2010). The 2 tubeworm species are known to colonise hard substrate from intertidal to sublittoral zones (Zibrowius 1971, Ben-Eliahu \& Fiege 1996, Çinar 2006, Çinar et al. 2006). They are generally gregarious organisms but sometimes can form small colonies (Çinar 2006). Serpulids are one of the most represented groups in encrusting benthic fouling communities, as well as a well-recognised component of NIS, showing a high structuring role in biofouling encrusting com- 
munities and a high degree of invasiveness (Çinar 2006, 2013, Çinar et al. 2014; see also Hove \& Kupriyanova 2009 and references therein). H. elegans and $H$. dirampha are recognised as major biofoulers on artificial hard substrata and are described as being among the most important threats to both local biodiversity and the socio-economy due to the damage they (i.e. calcareous tubes) can cause to human infrastructure and buildings (Zenetos et al. 2012, Çinar 2013). We investigated a 1 yr settlement of these 2 non-indigenous serpulid species and their role in shaping the hard substrate communities settled around fish farm cages. For this purpose, by using artificial panels close to the aquaculture cages, we also analysed the development of macrofouling communities when they undergo colonisation pressure exerted by the 2 tube-building serpulid species.

\section{MATERIALS AND METHODS}

\subsection{Experimental design and sampling}

The sampling collection phase took advantage of an experimental biofouling monitoring project (INNOVAQUA) performed in a system of aquaculture fish cages located in the northern part of the Strait of Sicily (Licata Harbour, Sicily) from 2014 to 2015 (Fig. 1). A total of 144 double-faced settlement panels $(10 \times 10 \mathrm{~cm}$ surface) were attached to 2 cages of the aquaculture plant. The experiment started in June 2014, and every 3 mo, 18 double-faced panels

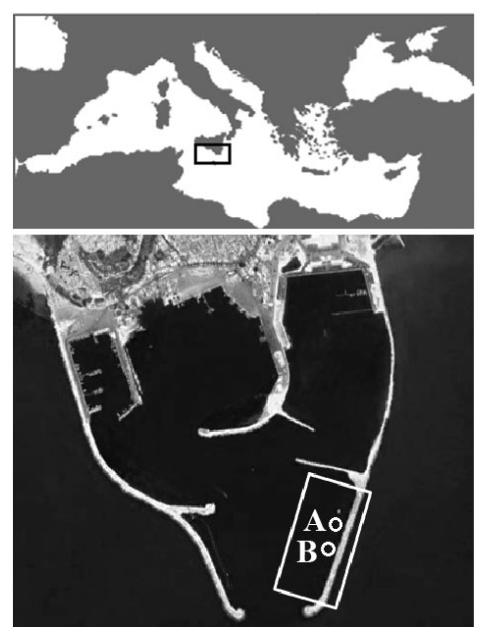

Sampling design model

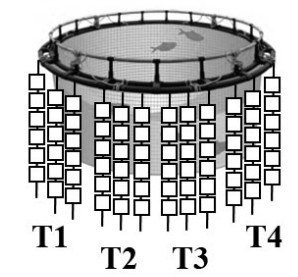

Fig. 1. Study area, Licata Harbour (northern side of Sicily Strait), showing the 2 cages (A and $B_{;} 100 \mathrm{~m}$ apart), and sampling design (each panel is double faced). Panels were collected every 3 mo $(n=18)$. T1: September 2014; T2: December 2014; T3: March 2015; T4: June 2015 were analysed (3 lines of 6 double-faced panels; 18 panels $\times 4$ periods $=72$ panels, repeated in 2 cages, i.e. 144 panels [thus 288 sides; see Fig. 1]). The panels were collected at 4 sampling times: in September 2014 (T1), December 2014 (T2); March 2015 (T3) and in June 2015 (T4), corresponding to 4 seasons (autumn, winter, spring, and summer, respectively). The 2 cages under investigation were located approx. $100 \mathrm{~m}$ apart and respectively contained about 75000 and 77000 specimens of Dicentrarchus labrax (Linnaeus, 1758) from June 2014 (3.8 and $3.6 \mathrm{~kg} \mathrm{~m}^{-3}$, respectively) to June 2015 (11.8 and $11.3 \mathrm{~kg}$ $\mathrm{m}^{-3}$, respectively). Continuous recorders of water temperature $\left({ }^{\circ} \mathrm{C}\right)$ and dissolved oxygen $\left(\mathrm{mg} \mathrm{l}^{-1}\right)$ were deployed at the 2 sites during the entire sampling period to detect any confounding effect due to the heterogeneity of local environmental variables.

\subsection{Macrofouling community analysis}

Once collected, the panels were transferred to the laboratory, and the fouling organisms were collected from the hard surfaces by scraping, fixed in a $10 \%$ formaldehyde-seawater solution and preserved in a $70 \%$ alcohol solution. Once washed through a 0.5 $\mathrm{mm}$ mesh sieve and sorted, the macrofouling specimens were individually identified to the lowest possible taxonomic level. A Leica M80 stereomicroscope and a Leica ICC50 HD optical microscope were used for taxonomic identification. Serpulid specimens were gently extracted from the tubes, identified (following Çinar 2006, Hove \& Kupriyanova 2009) and counted. The number of analysed specimens was standardised over the total sampling surface (i.e. serpulid density: serpulids $\mathrm{m}^{-2}$, mean $\pm \mathrm{SE}$ ).

Density and Margalef's species richness values (mean $\pm \mathrm{SE}$ ) were evaluated for the whole associated macrofouling community at each sampling time per each cage.

To assess the impact of NIS on macrofouling communities, we used the ALien Biotic IndEX (ALEX), proposed by Çinar \& Bakir (2014) and widely applied in the eastern Mediterranean basin. Species were categorised into 4 biogeographic groups: Group I (native species), Group II (casual species), Group III (established species) and Group IV (invasive species). The index, based on the percentages of abundance of each group within the community, classified the ecological status of studied area as follows:

$$
\begin{aligned}
\text { ALEX }= & \{(0 \times \% \text { GI })+[3 \times(\% \text { GII }+\% \text { GIII })] \\
& +(5 \times \% \text { GIV })\} / 100
\end{aligned}
$$


We calculated the index considering Hydroides elegans, H. dirampha, Anadara transversa (Say, 1822), Balanus trigonius Darwin, 1854, and Caprella scaura Templeton, 1836, in Group III (i.e. established species sensu Zenetos et al. 2010); Monocorophium acherusicum (Costa, 1853) and Ericthonius punctatus (Spence Bate, 1857) in Group II (i.e. casual species sensu Rumbold et al. 2016); and the other species in Group I (i.e. native species). The values of this index ranged from 0 to 5 . The value 0 indicates a community containing no alien species, whereas the value 5 indicates a community totally invaded by alien species (sensu Çinar \& Bakir 2014).

\subsection{Serpulid morphometric measurements}

Additionally, the (1) total body length from collar to pygidium (to the nearest $0.1 \mathrm{~mm}$ ), (2) operculum plus peduncle length (to the nearest $0.1 \mathrm{~mm}$ ) and (3) body weight (wet weight, to the nearest $0.1 \mathrm{mg}$ ) were measured. Trends in class sizes of abundance and biomass were presented for the total amount of sampled serpulids; the length-weight relationship was analysed for every sampling time, using the following allometric equation (Gould 1966, Dulčić \& Kraljević 1995):

$$
\mathrm{TW}=a \times \mathrm{TL}^{b}
$$

(linearised through base 10 logarithms; TW refers to the total body weight and TL to the total body length), together with the TL and operculum plus peduncle length relationship. The parameter $b$ in the linearised form was taken as an allometric coefficient equal to 3 in the case of isometric growth (sensu Gould 1966). Differences among both body length and body weight frequency distributions between the 2 serpulid species were tested through a coupled series of $t$-test combinations.

\subsection{Statistical analysis}

To test differences taking into account the 3 factors cage, species and time, a 3-way ANOVA test was performed considering the density of serpulids as a response variable. Differences between the associated fouler macrofaunal species at each of the 4 sampling times were assessed using multivariate techniques in the PRIMER (v.6) software package. A similarity matrix was calculated using the Bray-Curtis similarity index computed from the abundance data after a square root transformation to downweigh the influ- ence of extremely abundant species. Differences in abundance were related to sampling time categories and tested for significant differences using an ANOSIM test. A SIMPER routine was run to determine the species that contributed most to the average similarity among sampling times. A principal component analysis (PCA) was performed to highlight differences in macrofaunal community composition among sampling times. The average abundance of the serpulids, the density of associated macrofaunal species and the Margalef's index at each of the 4 sampling times were statistically tested with univariate analysis using 1-way ANOVA. All the ANOVA tests were applied after checking that the data conformed to the necessary assumptions regarding homogeneity of variance and normality using Levene's and Anderson-Darling tests, respectively; data were $\log 10(x+1)$ transformed when necessary. Differences among categories were tested using the Student-NewmanKeuls (SNK) test (significant interaction terms were considered at $\mathrm{p}<0.05, \mathrm{p}<0.001, \mathrm{p}<0.0001$ ).

A distance-based linear model routine (DistLM, Legendre \& Anderson 1999), based on Bray-Curtis dissimilarities (using the $\mathrm{R}^{2}$ selection criterion and stepwise selection procedure), was applied to disentangle potential effects of the presence of serpulid NIS or by the environmental variables (i.e. in situ measured sea temperature and dissolved oxygen) in shaping macrofaunal abundance, community composition and diversity.

Values of temperature, oxygen and serpulid abundance were normalised and used as the predictor variable worksheet in DistLM analysis after a draftsman plot (Clarke \& Gorley 2006) was carried out to detect possible skewness and/or strong correlation $(R>0.7)$ between environmental variables and abundance of serpulid species.

\section{RESULTS}

\subsection{Environmental parameters}

No differences in temperature and dissolved oxygen were detected between the 2 cages for each sampling time (Fig. 2).

\subsection{Serpulid densities and morphometric results}

No differences in density were detected between the 2 serpulid species sampled at each cage at each 

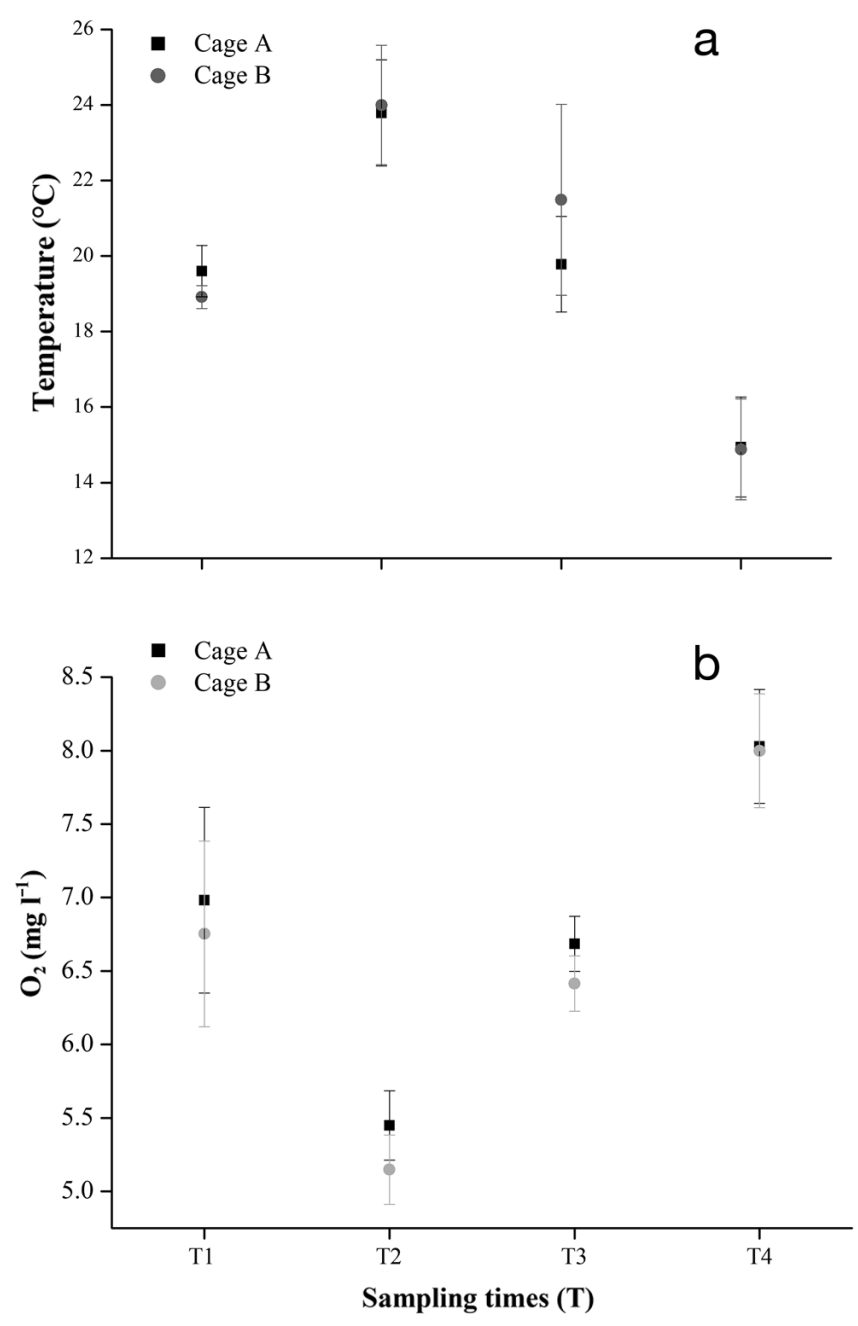

Fig. 2. Mean \pm SE (a) temperature and (b) dissolved oxygen for the 4 sampling times (see Fig. 1)

sampling time; significant differences were shown only for the last factor, time, with the same response trend for the 2 species (3-way ANOVA, factor cage, $F_{1,1}=1.50, \mathrm{p}=0.235$; factor species, $F_{1,1}=0.16, \mathrm{p}=$ 0.690 ; factor time, $F_{1,3}=10.26, \mathrm{p}=0.001$ ).

Differences were detected in the length and weight frequency distributions (Figs. $3 \& 4$ ) of the 2 serpulid species (Table 1); all were significant ( $t$-tests, TL $H y$ droides dirampha $\neq H$. elegans, $t=-1.55, \mathrm{p}=0.135$; TW $H$. dirampha $\neq H$. elegans, $t=-1.39, \mathrm{p}=0.176$ ).

Linear regressions between total body length and operculum plus peduncle length were all significant and indicated a negative allometry $(b<1)$ for both serpulid species examined, $H$. dirampha $(b=0.677)$ and $H$. elegans $(b=0.064)$ (Table 1$)$. Also, growth appeared to show a tendency toward a negative allometry for $H$. dirampha $(b=1.185)(b<3$; Table 1$)$, while $H$. elegans did not show a significant allometric relationship between biometric variables $(p=0.121$; $b=0.493)$.

The mean density values of serpulids analysed along the 4 sampling times showed different trends at each sampling time (ANOSIM, R = 0.729, p < 0.05; Fig. 5).

Between the 2 sampled serpulids, $H$. dirampha was always the most abundant (Fig. 5; ANOVA, factor sampling time, $F_{1,3}=6.77, \mathrm{p}=0.007$; SNK test, T3 $>$ T1, $\mathrm{T} 2, \mathrm{~T} 4, \mathrm{p}=0.043$ ), followed by $H$. elegans (ANOVA, factor sampling time, $F_{1,3}=8.05, \mathrm{p}=0.032$; SNK test, $\mathrm{T} 3>\mathrm{T} 1, \mathrm{~T} 2, \mathrm{~T} 4, \mathrm{p}=0.036)$. The density pattern between the 2 species through the sampling time was the same, or rather, both started settling 9 mo after panel displacements, during spring (T3; Fig. 5). Densities drastically decreased in summer, favouring some of the associated macrofaunal species such as the crustaceans Elasmopus rapax Costa, 1853, and Jassa marmorata Holmes, 1905; the polychaete Syllis gracilis Grube, 1840; and the ascidian Styela plicata (Lesueur, 1823) (Table 2, Supplement atwww.int-res. com/articles/suppl/q011p041_supp.pdf).

\subsection{Macrofouling community structure}

Peaks of associated macrofauna density values were recorded at both $\mathrm{T} 1$ and $\mathrm{T} 2$, ANOVA test, $F_{1,3}=$ 10.84, p < 0.05; pairwise test, T1, T2 > T3, T4, p < 0.05; Fig. 5); a visible decrease was recorded at T3, the sampling time at which we observed a dominance of Serpulidae (maximum serpulid density values $H$. dirampha $=535$ ind. $\mathrm{m}^{-2}, H$. elegans $=270$ ind. $\mathrm{m}^{-2}$ ). The highest values for Margalef's species richness calculated for the associated macrofaunal community were recorded at both $\mathrm{T} 2$ and $\mathrm{T} 4$, with the maximum value recorded at sampling time T4 (ANOVA, $F_{1,3}=$ 18.65, p < 0.01; pairwise test, T4 > T1, T3, p $<0.001$, $\mathrm{T} 4>\mathrm{T} 2, \mathrm{p}<0.05$; Fig. 6). Among the 16 most abundant associated macrofaunal species (SIMPER outcomes, Table 2), there were 2 small non-indigenous peracaridan (amphipod; crustaceans) species, Monocorophium acherusicum and Ericthonius punctatus, both natives from the North Atlantic. The second most abundant associated macrofaunal species was the tanaidacean Tanais dulongii (Audouin, 1826) that showed significantly higher abundance at sampling time T2 (winter) compared to T4 (summer). Jassa marmorata and the peracaridan gammarid Elasmopus rapax showed increasing trends, with the highest average abundance values at T4. The polychaete Syllis gracilis was more abundant at T4 compared to T2. The barnacle Balanus trigonus showed a peak 

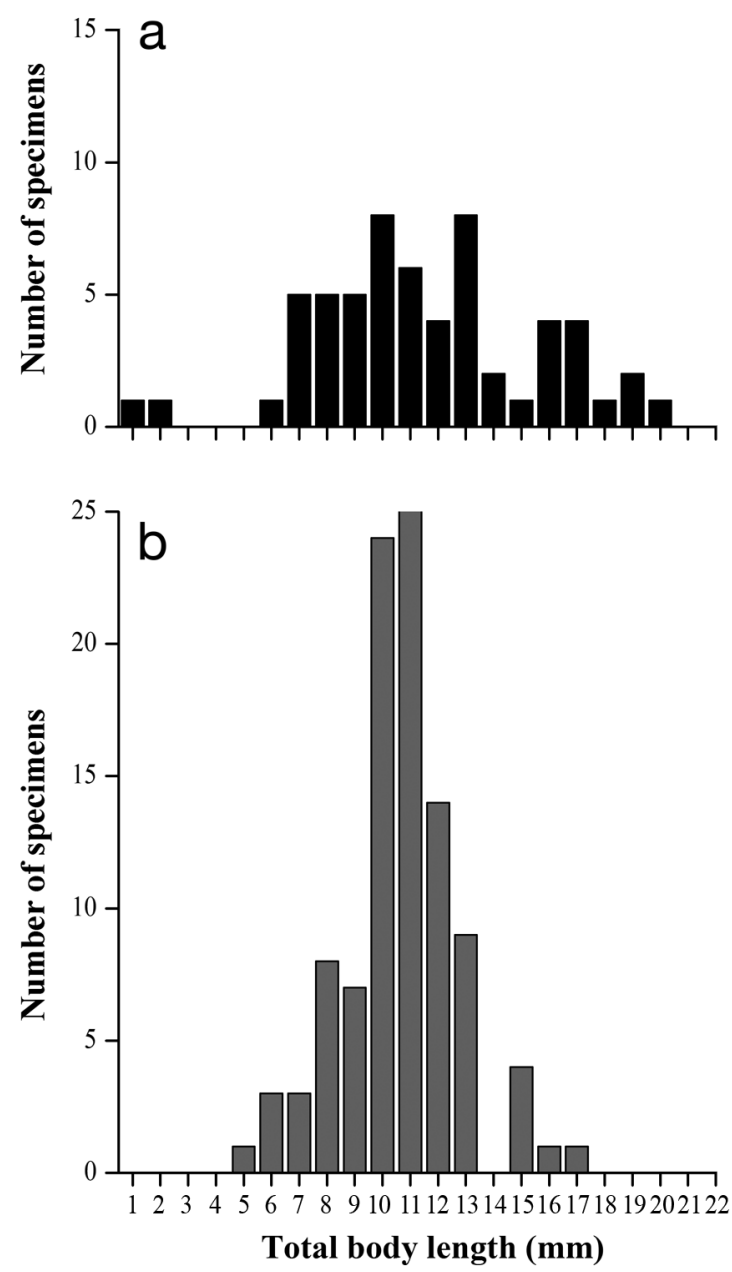

Fig. 3. Body length frequencies of (a) Hydroides dirampha and (b) H. elegans

corresponding with the highest densities of serpulids. The solitary ascidian Styela plicata showed a significant increasing trend from T1 to T4. Both of the 2 most abundant caprellid associated native species, Caprella dilatata and $C$. equilibra, showed no differences among the sampling periods, similar to the tanaidacean Chondrochelia savignyi (Kroyer, 1842) and the 3 most abundant polychaetes, Spirobranchus
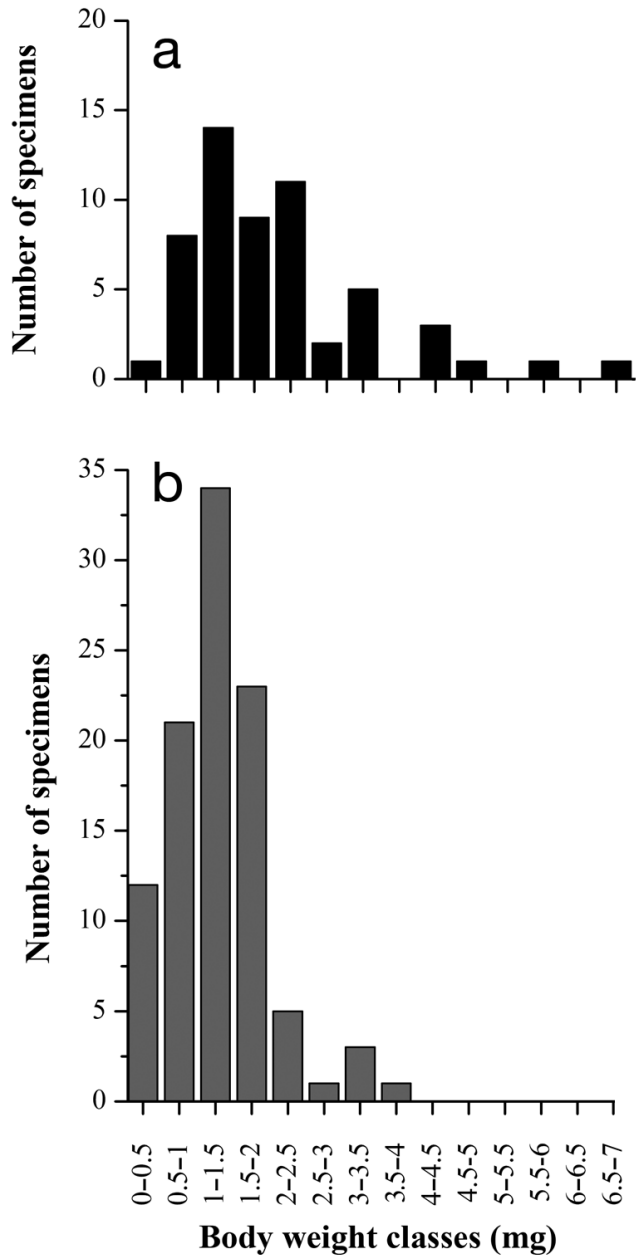

Fig. 4. Body weight frequencies of (a) Hydroides dirampha and (b) H. elegans

triqueter (Linnaeus, 1758), Nereis sp. and Branchiomma bombyx (Dalyell, 1853), and the bivalve Musculus discors (Linnaeus, 1767). Another serpulid species, Hydroides dianthus (Verril, 1873), was found; previously considered a NIS, it was only recently identified as indigenous according to a molecular study (Sun et al. 2017, Zenetos et al. 2017). This species showed a density pattern similar to the other 2

Table 1. Hydroides dirampha and $H$. elegans total length (TL, mm) and total weight (TW, mg) (range and mean \pm SE) and linear regression between TW and TL and between TL and operculum plus peduncle (OP) length

\begin{tabular}{|lccccc|}
\hline Species & TL range & TL mean \pm SE & TW vs. TL & R & p \\
\hline H. dirampha & $6-20$ & $12 \pm 3.74$ & TW $=1.185-1.01$ TL & 0.55 & $<0.0001$ \\
H. elegans & $5-17$ & $11 \pm 2.12$ & TW $=0.494-0.493$ TL & 0.155 & 0.121 \\
& TW range & TW mean \pm SE & TL vs. OP & & \\
& & $2.2 \pm 1.7$ & TL $=0.677-0.278$ OP & 0.76 & $<0.0001$ \\
\hline H. dirampha & $0.3-9.2$ & $1.2 \pm 0.6$ & TL $=0.064-0.268$ OP & 0.62 & $<0.0001$ \\
H. elegans & $0.2-4.0$ & 100 & 100 \\
\hline
\end{tabular}




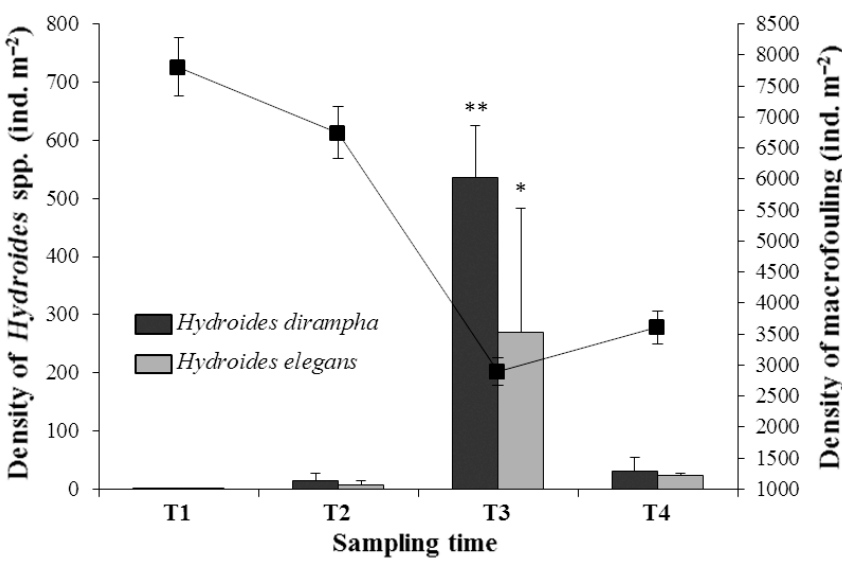

Fig. 5. Mean $( \pm \mathrm{SE})$ densities of non-indigenous Hydroides spp. (bars) and of other macrofouling species (black squares) at different sampling times (see Fig. 1). Significant highest values of density were reported for the 2 serpulids at T3. ${ }^{*} \mathrm{p}<0.05,{ }^{* *} \mathrm{p}<0.01$

NIS serpulids, with a peak in abundance at T3 (SIMPER, Table 2). In PCA, performed on the 16 most abundant associated macrofaunal species, the first 2 axes explained $86.6 \%$ of the variance. We observed that T1 and T2, characterised by higher abundance of Monocorophium acherusicum, Ericthonius punctatus and Tanais dulongii, were clearly separated from T3, where we observed higher abundance of Balanus trigonus, $H$. dianthus and Branchiomma bombyx, and T4, characterised by higher abundance of Styela plicata and Syllis gracilis (Fig. 7).

The DistLM analysis showed that the environmental variables did not explain macrofouling abundance, diversity and composition. The presence of the 2 serpulids did not significantly influence the abundance and diversity of macrofauna; only the variations in community composition were significantly explained by the abundance of $H$. dirampha (32\%, Table 3$)$.

A score of 2, a Good status for fouling communities in terms of the impact of alien species (sensu Çinar \& Bakir 2014), was obtained by evaluating the ALEX index.

\section{DISCUSSION}

Here we have provided morphometric measurements of 2 NIS serpulids and evidence supporting their well-recognised enhanced capacity for colonisation (Relini 1993, Denitto \& Licciano 2006). The density values of the serpulids in the present study are comparable with other studies performed in the eastern Mediterranean basin (Alsancak Harbour at Izmir Bay; Çinar et al. 2008). Our novel data for the study area will integrate the available information on the presence of Hydroides elegans and H. dirampha for the whole basin. The gathered information may also confirm the westward spread pattern across the central Mediterranean Sea, a hydrodynamically crucial area with $90 \%$ of nautical traffic traversing and human activities through the Malta-Sicily Channel (Katsanevakis et al. 2014, 2016, Deidun et al. 2016, Mangano \& Sarà 2017, Capodici et al. 2018). Ship hulls are considered the most probable vectors of translocation, and pier fouling, harbour docks and aquaculture infrastructures are considered the main hotspots of aggregation for these species (Ben-Eliahu \& Hove 2011). H. elegans is one of the most studied serpulids in the Mediterranean Sea and is considered the primary fouling organism in the Mediterranean Sea on both hard and soft substrata (Koçak et al. 1999, Çinar et al. 2006, Cabanellas-Reboredo et al. 2010, Ben-Eliahu \& Hove 2011), including aquaculture structures and equipment (Katsanevakis et al. 2014). The settlement patterns of the 2 serpulids where similar, with a peak during spring followed by a decline in abundance in summer, which also has been recorded for other Lessepsian immigrant serpulid polychaetes (Belal \& Ghobashy 2012).

Our results highlight the significant role of the 2 serpulid NIS, in particular of the most abundant species, H. dirampha, in shaping the macrofouling community (DistLM analysis) and confirm the community-shaping power of these species. In fact, most of the macrofaunal species showed a visible decrease in abundance during the period dominated by the 2 serpulid species (spring) and a subsequent increase during summer. Our results are consistent with previous observations by Lezzi et al. (2018), which suggested that $H$. elegans and $H$. dirampha behave as r-selected pioneer species, structuring components of early communities, but after settlement, they are not able to develop in late communities. We observed that some sessile components of the community, principally represented by the native serpulid $H$. dianthus, the sabellid Branchiomma bombyx and the balanid Balanus trigonius (NIS according to Zenetos et al. 2010), showed a peak of abundance during spring, corresponding with the highest densities of the 2 serpulid NIS in this study. This suggests that sessile NIS recruitment on hard substrate can co-occur with that of other sessile species (Lezzi et al. 2018), and that $H$. elegans and $H$. dirampha are able to settle despite high competition for space with other sessile organisms during their recruitment. On the other hand, the 
Table 2. SIMPER analysis for the 16 most abundant species at each of the considered 4 sampling times (see Fig. 1). C: crustacean; A: ascidian; P: polychaete; M: mollusc

\begin{tabular}{|c|c|c|c|}
\hline Code & Species & $\begin{array}{c}\text { Avg. } \\
\text { abundance } \\
\left(\text { ind. } \mathrm{m}^{-2} \text { ) }\right.\end{array}$ & $\begin{array}{c}\text { Contri- } \\
\text { bution } \\
(\%)\end{array}$ \\
\hline \multicolumn{4}{|c|}{ T1 (avg. similarity = 70.58) } \\
\hline $\mathrm{C}$ & Monocorophium acherusicum (Costa, 1853) & 5682.0 & 42.5 \\
\hline $\mathrm{C}$ & Tanais dulongii (Audouin, 1826) & 1158.0 & 19.47 \\
\hline $\mathrm{C}$ & Ericthonius punctatus (Spence Bate, 1857) & 364.0 & 11.92 \\
\hline $\mathrm{P}$ & Spirobranchus triqueter (Linnaeus, 1758) & 266.0 & 6.64 \\
\hline $\mathrm{C}$ & Chondrochelia savignyi (Kroyer, 1842) & 100.5 & 2.75 \\
\hline $\mathrm{P}$ & Nereis sp. & 36.0 & 2.75 \\
\hline $\mathrm{C}$ & Caprella equilibra Say, 1818 & 10.0 & 2.32 \\
\hline M & Musculus discors (Linnaeus, 1767) & 72.0 & 2.32 \\
\hline $\mathrm{C}$ & Balanus trigonus Darwin, 1854 & 43.0 & 1.87 \\
\hline \multicolumn{4}{|c|}{ T2 (avg. similarity $=\mathbf{7 6 . 3 6}$ ) } \\
\hline $\mathrm{C}$ & Monocorophium acherusicum (Costa, 1853) & 3982.0 & 39.00 \\
\hline $\mathrm{C}$ & Tanais dulongii (Audouin, 1826) & 2028.0 & 22.85 \\
\hline $\mathrm{P}$ & Spirobranchus triqueter (Linnaeus, 1758) & 81.0 & 5.26 \\
\hline $\mathrm{C}$ & Ericthonius punctatus (Spence Bate, 1857) & 274.0 & 3.72 \\
\hline $\mathrm{P}$ & Nereis sp. & 45.0 & 3.55 \\
\hline A & Styela plicata (Lesueur, 1823) & 35.0 & 3.49 \\
\hline $\mathrm{C}$ & Balanus trigonus Darwin, 1854 & 33.5 & 3.11 \\
\hline $\mathrm{C}$ & Chondrochelia savignyi (Kroyer, 1842) & 30.0 & 2.82 \\
\hline $\mathrm{C}$ & Jassa marmorata Holmes, 1905 & 42.5 & 2.34 \\
\hline $\mathrm{P}$ & Branchiomma bombyx (Dalyell, 1853) & 27.5 & 2.05 \\
\hline $\mathrm{C}$ & Caprella dilatata Kroyer, 1843 & 26.5 & 2.05 \\
\hline $\mathrm{C}$ & Elasmopus rapax Costa, 1853 & 15.0 & 1.75 \\
\hline $\mathrm{C}$ & Caprella equilibra Say, 1818 & 13.0 & 1.66 \\
\hline $\mathrm{P}$ & Syllis gracilis Grube, 1840 & 7.0 & 1.52 \\
\hline \multicolumn{4}{|c|}{ T3 (avg. similarity $=65.87$ ) } \\
\hline $\mathrm{C}$ & Balanus trigonus Darwin, 1854 & 1119.0 & 22.46 \\
\hline $\mathrm{C}$ & Monocorophium acherusicum (Costa, 1853) & 622.0 & 16.75 \\
\hline $\mathrm{C}$ & Tanais dulongii (Audouin, 1826) & 514.0 & 15.23 \\
\hline $\mathrm{P}$ & Branchiomma bombyx (Dalyell, 1853) & 103.0 & 6.82 \\
\hline A & Styela plicata (Lesueur, 1823) & 95.0 & 5.82 \\
\hline $\mathrm{P}$ & Syllis gracilis Grube, 1840 & 73.5 & 5.58 \\
\hline $\mathrm{P}$ & Hydroides dianthus (Verrill, 1873) & 161.5 & 5.54 \\
\hline $\mathrm{C}$ & Ericthonius punctatus (Spence Bate, 1857) & 39.0 & 3.29 \\
\hline $\mathrm{P}$ & Spirobranchus triqueter (Linnaeus, 1758) & 32.0 & 2.93 \\
\hline $\mathrm{C}$ & Caprella equilibra Say, 1818 & 37.5 & 2.90 \\
\hline $\mathrm{P}$ & Nereis sp. & 45.5 & 2.85 \\
\hline $\mathrm{C}$ & Elasmopus rapax Costa, 1853 & 74.0 & 2.69 \\
\hline $\mathrm{C}$ & Jassa marmorata Holmes, 1905 & 15.0 & 2.51 \\
\hline \multicolumn{4}{|c|}{ T4 (avg. similarity = 73.08) } \\
\hline $\mathrm{C}$ & Monocorophium acherusicum (Costa, 1853) & 1603.0 & 20.54 \\
\hline $\mathrm{A}$ & Styela plicata (Lesueur, 1823) & 346.5 & 9.12 \\
\hline $\mathrm{C}$ & Tanais dulongii (Audouin, 1826) & 361.0 & 8.29 \\
\hline $\mathrm{C}$ & Elasmopus rapax Costa, 1853 & 227.0 & 7.73 \\
\hline $\mathrm{C}$ & Jassa marmorata Holmes, 1905 & 208.0 & 7.4 \\
\hline $\mathrm{C}$ & Ericthonius punctatus (Spence Bate, 1857) & 33.0 & 6.84 \\
\hline $\mathrm{P}$ & Spirobranchus triqueter (Linnaeus, 1758) & 123.0 & 5.33 \\
\hline $\mathrm{P}$ & Nereis sp. & 78.0 & 3.94 \\
\hline $\mathrm{C}$ & Chondrochelia savignyi (Kroyer, 1842) & 74.0 & 3.66 \\
\hline $\mathrm{C}$ & Balanus trigonus Darwin, 1854 & 103.0 & 3.59 \\
\hline $\mathrm{C}$ & Caprella equilibra Say, 1818 & 143.0 & 3.4 \\
\hline $\mathrm{P}$ & Branchiomma bombyx (Dalyell, 1853) & 65.5 & 3.36 \\
\hline $\mathrm{P}$ & Syllis gracilis Grube, 1840 & 83.0 & 2.29 \\
\hline $\mathrm{C}$ & Caprella dilatata Kroyer, 1843 & 35.0 & 1.99 \\
\hline
\end{tabular}

highest abundance of mobile organisms and the high diversity level of associated macrofauna recorded at T4 could suggest a facilitating effect exerted by NIS. By modifying the habitat properties, the NIS may attract more diverse and abundant mobile native and non-native species (e.g. offering shelter and refuge within their encrusting calcareous tubes; Floerl et al. 2004, Stachowicz \& Byrnes 2006).

Within the macrofouling community, interestingly, the 2 small nonindigenous peracaridan species, Monocorophium acherusicum and Ericthonius punctatus, have been recorded as dominant compared to native species, especially in harbour areas and in other Mediterranean areas (Rumbold et al. 2016). Hard substrata provided by fish farm components seem to represent the perfect artificial habitat to investigate the settlement of benthic NIS (Maughan 2001, Bowden et al. 2006) and are confirmed as NIS hotspots by our results. The result of the calculation of ALEX, a new and recently applied biotic index in the western Mediterranean basin (e.g. monitoring macroalgae, Piazzi et al. 2015, 2018) and applied here for the first time on a fouling community in the central basin, showed a fouling community which has alien species, but the majority of organisms belong to native species (Good status sensu Çinar \& Bakir 2014). The occurrence of the 2 serpulid species on fish farm structures may also depend on the high food resources availability on the local scale, i.e. the large amount of particulate waste output from sea bream/sea bass farming. As a result of all these observations, fish aquaculture might be confirmed as a main driver in favouring the spread of both the investigated serpulids and the macrobenthic community primarily structured by these. The obtained results will integrate, update and complete the current status of knowledge regarding these small migrant serpulids in the Mediterranean basin by adding evidence on their settlement 


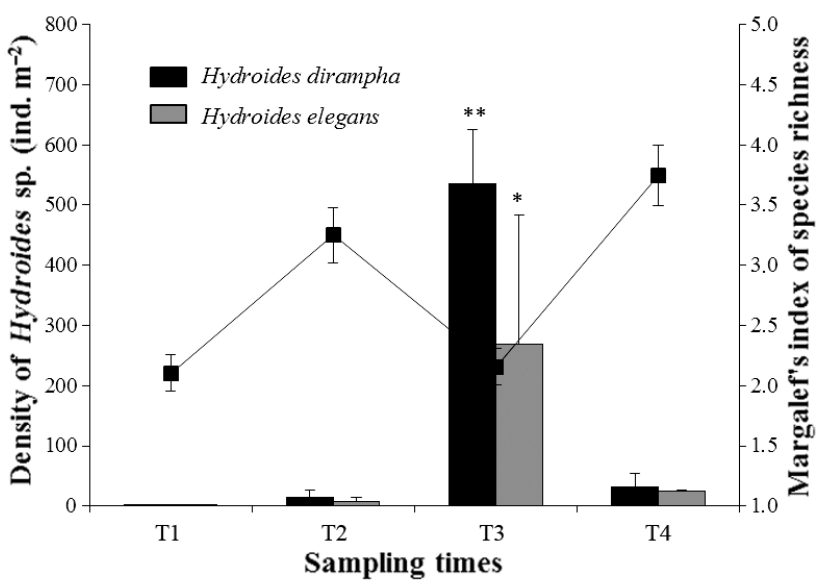

Fig. 6. Mean $( \pm \mathrm{SE})$ densities of non-indigenous Hydroides spp. (bars) and the Margalef's species richness index (calculated excluding the 2 serpulid species) for the 4 sampling times (see Fig. 1). Significant highest values of density were reported for the 2 serpulids at T3 $\left({ }^{*} p<0.05,{ }^{* *} p<0.01\right)$

along a $1 \mathrm{yr}$ time series and showing differences in the associated macrofaunal diversity. Serpulids, in fact, can easily remain undetected (Zenetos et al. 2005), and even if the number of observations of invasive migrants has greatly increased in the last 3 decades, our knowledge about Lessepsian serpulids is still scant. These small creatures have been sampled only sporadically, and information about them remains presumably limited to the taxa that have already built up sizeable populations (Çinar 2006), as in our case.

The preliminary data discussed here on the diversity and density of the associated macrofaunal community suggest a founder facilitating effect promoted

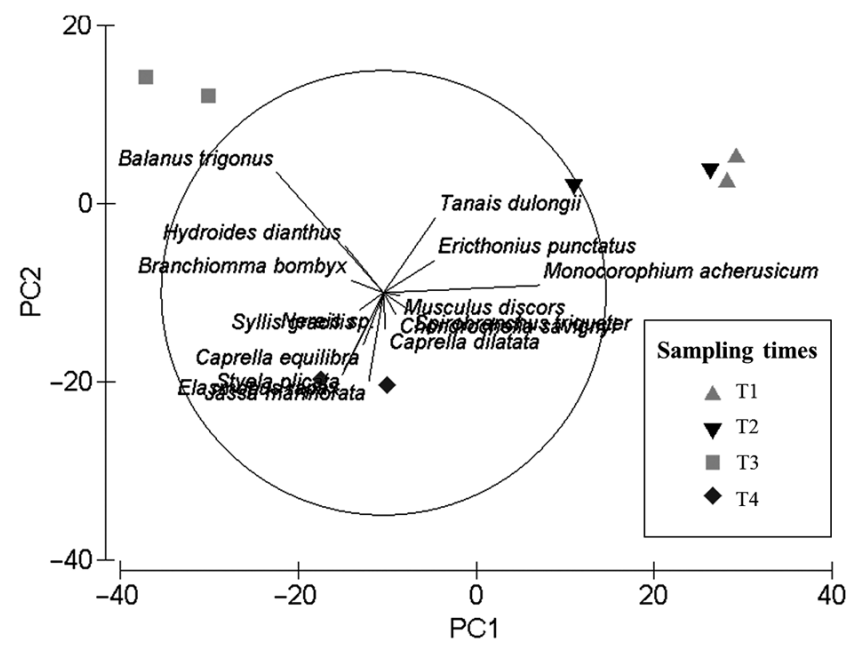

Fig. 7. Principal component analysis performed on square root transformed data of 16 most abundant macrofaunal species during the 4 sampling time periods (see Fig. 1). The first 2 axes explained $86.6 \%$ of the variance
Table 3. DistLM analysis to ascertain the role of environmental variables (temperature and oxygen) and abundance of the 2 serpulid species (Hydroides dirampha and $H$. elegans) on macro-faunal community composition. ns: not significant. ${ }^{* *} \mathrm{p}<0.001$

\begin{tabular}{|lccccc|}
\hline Variable & SS & $F$ & p & $\begin{array}{c}\text { Var. } \\
(\%)\end{array}$ & $\begin{array}{c}\text { Cumulative } \\
\%\end{array}$ \\
\hline H. dirampha & 1828.9 & 2.8 & ${ }^{* *}$ & 0.32 & 0.32 \\
Temperature & 1119.2 & 2.0 & ns & 0.20 & 0.52 \\
Dissolved oxygen & 788.8 & 1.6 & ns & 0.14 & 0.66 \\
H. elegans & 542.0 & 1.1 & ns & 0.09 & 0.75 \\
\hline
\end{tabular}

by serpulids worthy of further future investigation through setting up a more focused monitoring plan (extended in time and space) in relation to local environmental variables and to species resistance. NIS may negatively interact with local biodiversity or cause risks and threats to human activities, generating high economic costs (e.g. farm cage cleaning in aquaculture sectors; Floerl et al. 2016). In this regard, monitoring plans, as the one presented here, should be encouraged and promoted as a main solution to improve the management and regulation of introduced fauna in the Mediterranean region (Lehtiniemi et al. 2015, Ojaveer et al. 2015, Galil et al. 2018).

Acknowledgements. Samples were collected in the framework of the INNOVAQUA project (PON Ricerca and Competitività 2007-2013 MIUR). This research was partially supported by the RITMARE Ricerca ITaliana per il MARE project SP2_WP4_AZ1_UO01 MIUR 2012-2016. M.C.M. was granted a postdoctoral scholarship from the IAMC-CNR (IAMC-009-2014-TP). We thank all the people at the Laboratory of Experimental Ecology (gsaralab) for the help offered during the sampling and processing phases.

\section{LITERATURE CITED}

Belal AAM, Ghobashy AFA (2012) Settlement behaviour and description of the Lessepsian immigrant of the serpulid polychaete Pomatoleios kraussii in the Suez Bay. Egypt J Aquat Res 38:23-30

*Ben-Eliahu MN, Fiege D (1996) Serpulid tube-worms (Annelida: Polychaeta) of the central and eastern Mediterranean with particular attention to the Levant Basin. Senckenb Marit 28:1-51

Ben-Eliahu MN, Hove HT (2011) Serpulidae (Annelida: Polychaeta) from the Suez Canal: from a Lessepsian migration perspective (a monograph). Zootaxa 2848:1-147

Bowden DA, Clarke A, Peck LS, Barnes DKA (2006) Antarctic sessile marine benthos: colonisation and growth on artificial substrata over three years. Mar Ecol Prog Ser 316:1-16

Bramanti L, Magagnini G, Santangelo G (2003) Settlement and recruitment: the first stages in the life cycle of two 
epibenthic suspension feeders (Corallium rubrum and Anomia ephippium). Ital J Zool 70:175-178

Byers JE, Smith RS, Pringle JM, Clark GF and others (2015) Invasion expansion: time since introduction best predicts global ranges of marine invaders. Sci Rep 5:12436

Cabanellas-Reboredo M, Deudero S, Alos J, Hendriks I (2010) Initial data on settlement and recruitment of macrobenthic organisms on artificial substrates located over Posidonia oceanica meadows. Mar Biol Res 6:591-599

Capodici F, Ciraolo G, Cosoli S, Maltese A, Mangano MC, Sarà G (2018) Downscaling hydrodynamics features to depict causes of major productivity of Sicilian-Maltese area and implications for resource management. Sci Total Environ 628-629:815-825

* Cardeccia A, Marchinia A, Occhipinti-Ambrogi A, Galil B and others (2018) Assessing biological invasions in European seas: biological traits of the most widespread nonindigenous species. Estuar Coast Shelf Sci 201:17-28

* Çinar ME (2006) Serpulid species (Polychaeta: Serpulidae) from the Levantine coast of Turkey (eastern Mediterranean), with special emphasis on alien species. Aquat Invasions 1:223-240

* Çinar ME (2013) Alien polychaete species worldwide: current status and their impacts. J Mar Biol Assoc UK 93: 1257-1278

* Çinar ME, Bakir K (2014) ALien Biotic IndEX (ALEX)a new index for assessing impacts of alien species on benthic communities. Mar Pollut Bull 87:171-179

* Çinar ME, Katağan T, Öztürk B, Egemen Ö and others (2006) Temporal changes of soft-bottom zoobenthic communities in and around Alsancak Harbor (Izmir Bay, Aegean Sea), with special attention to the autecology of exotic species. Mar Ecol 27:229-246

* Çinar ME, Katağan T, Koçak F, Öztürk B and others (2008) Faunal assemblages of the mussel Mytilus galloprovincialis in and around Alsancak Harbour (Izmir Bay, eastern Mediterranean) with special emphasis on alien species. J Mar Syst 71:1-17

* Çinar ME, Dağli E, Şahin GK (2014) Checklist of Annelida from the coasts of Turkey. Turk J Zool 38:734-764

Clarke KR, Gorley RN (2006) PRIMER v6: user manual/ tutorial. PRIMER-E, Plymouth

Deidun A, Andaloro F, Berti C, Consoli P and others (2016) Assessing the potential of Suez Canal shipping traffic as an invasion pathway for non-indigenous species in central Mediterranean harbours. Rapp Comm Int Mer Medit 41:429

Denitto F, Licciano M (2006) Recruitment of Serpuloidea (Annelida: Polychaeta) in a marine cave of the Ionian Sea (Italy, central Mediterranean). J Mar Biol Assoc UK 86: 1373-1380

* Didham RK, Tylianakis JM, Gemmell NJ, Rand TA, Ewers RM (2007) Interactive effects of habitat modification and species invasion on native species decline. Trends Ecol Evol 22:489-496

Wulčić J, Kraljević M (1995) Age, growth and mortality of damselfish (Chromis chromis L.) in the eastern middle Adriatic. Fish Res 22:255-264

European Commission (2008) Directive 2008/56/EC of the European Parliament and the Council of 17 June 2008 establishing a framework for community action in the field of marine environmental policy (Marine Strategy Framework Directive). Off J Eur Union 164:19-40

Fernandez-Gonzalez V, Sanchez-Jerez P (2014) First occurrence of Caprella scaura Templeton, 1836 (Crustacea:
Amphipoda) on off-coast fish farm cages in the Mediterranean Sea. Helgol Mar Res 68:187-191

*FFletcher DH, Gillingham PK, Britton JR, Blanchet S, Gozlan RE (2016) Predicting global invasion risks: a management tool to prevent future introductions. Sci Rep 6: 26316

Floerl O, Pool TK, Inglis GJ (2004) Positive interactions between nonindigenous species facilitate transport by human vectors. Ecol Appl 14:1724-1736

*Floerl O, Sunde LM, Bloecher N (2016) Potential environmental risks associated with biofouling management in salmon aquaculture. Aquacult Environ Interact 8:407-417

*Galil BS, Marchini A, Occhipinti-Ambrogi A, Minchin D, Narščius A, Ojaveer H, Olenin S (2014) International arrivals: widespread bioinvasions in European seas. Ethol Ecol Evol 26:152-171

* Galil BS, Marchini A, Occhipinti-Ambrogi A (2018) East is east and west is west? Management of marine bioinvasions in the Mediterranean Sea. Estuar Coast Shelf Sci 201:7-16

*Gould SJ (1966) Allometry and size in ontogeny and phylogeny. Biol Rev Camb Philos Soc 41:587-638

Hewitt CL, Everett RA, Parker N, Campbell ML (2009) Marine bioinvasion management: structural framework. In: Rilov G, Crooks JA (eds) Biological invasions in marine ecosystems-ecological, management, and geographic perspectives. Springer-Verlag, Heidelberg, p 327-334

Hove H, Kupriyanova EK (2009) Taxonomy of Serpulidae (Annelida, Polychaeta): the state of affairs. Zootaxa 2036: 1-126

* Hulme PE, Pauchard A, Pyšek P, Vilà M and others (2015) Challenging the view that invasive non-native plants are not a significant threat to the floristic diversity of Great Britain. Proc Natl Acad Sci USA 112:E2988-E2989

ICES (2016) Report of the working group on introductions and transfers of marine organisms (WGITMO), 16-18 March 2016, Olbia, Italy. ICES CM 2016/SSGEPI:10

Katsanevakis S, Wallentinus I, Zenetos A, Leppäkoski E and others (2014) Impacts of invasive alien marine species on ecosystem services and biodiversity: a pan-European review. Aquat Invasions 9:391-423

Katsanevakis S, Tempera F, Teixeira H (2016) Mapping the impact of alien species on marine ecosystems: the Mediterranean Sea case study. Divers Distrib 22:694-707

*Koçak F, Ergen Z, Çinar ME (1999) Fouling organisms and their developments in a polluted and an unpolluted marina in the Aegean Sea (Turkey). Ophelia 50:1-20

Kumschick S, Gaertner M, Vilà M, Essl F and others (2015) Ecological impacts of alien species: quantification, scope, caveats, and recommendations. Bioscience 65:55-63

* Legendre P, Anderson MJ (1999) Distance-based redundancy analysis: testing multispecies responses in multifactorial ecological experiments. Ecol Monogr 69:1-24

Lehtiniemi M, Ojaveer H, David M, Galil B and others (2015) Dose of truth-monitoring marine non-indigenous species to serve legislative requirements. Mar Policy 54: 26-35

* Lezzi M, Del Pasqua M, Pierri C, Giangrande A (2018) Seasonal non-indigenous species succession in a marine macrofouling invertebrate community. Biol Invasions 20: 937-961

*Mangano MC, Sarà G (2017) Collating science-based evidence to inform public opinion on the environmental effects of marine drilling platforms in the Mediterranean Sea. J Environ Manage 188:195-202 
Martell L, Bracale R, Carrion SA, Purcell JE and others (2018) Successional dynamics of marine fouling hydroids (Cnidaria: Hydrozoa) at a finfish aquaculture facility in the Mediterranean Sea. PLOS ONE 13:e0196883

Maughan BC (2001) The effects of sedimentation and light on recruitment and development of a temperate, subtidal, epifaunal community. J Exp Mar Biol Ecol 256: 59-71

Meiners SJ, Pickett STA, Cadenasso ML (2001) Effects of plant invasions on the species richness of abandoned agricultural land. Ecography 24:633-644

* Molnar JL, Gamboa RL, Revenga C, Spalding MD (2008) Assessing the global threat of invasive species to marine biodiversity. Front Ecol Environ 6:485-492

Nunes AL, Katsanevakis S, Zenetos A, Cardoso AC (2014) Gateways to alien invasions in the European seas. Aquat Invasions 9:133-144

* Ojaveer H, Galil BS, Minchin D, Olenin S and others (2014) Ten recommendations for advancing the assessment and management of non-indigenous species in marine ecosystems. Mar Policy 44:160-165

* Ojaveer H, Galil BS, Campbell ML, Carlton JT and others (2015) Classification of non-indigenous species based on their impacts: considerations for application in marine management. PLOS Biol 13:e1002130

Piazzi L, Gennaro P, Ceccherelli G (2015) Suitability of the ALien Biotic IndEX (ALEX) for assessing invasion of macroalgae across different Mediterranean habitats. Mar Pollut Bull 97:234-240

Piazzi L, Gennaro P, Atzori F, Cadoni N, Cinti MF, Frau F, Ceccherelli G (2018) ALEX index enables detection of alien macroalgae invasions across habitats within a marine protected area. Mar Pollut Bull 128:318-323

Pyšek P, Richardson DM (2010) Invasive species, environmental change and management, and health. Annu Rev Environ Resour 35:25-55

Ramsay A, Davidson J, Landry T, Arsenault G (2008) Process of invasiveness among exotic tunicates in Prince Edward Island, Canada. Biol Invasions 10:1311-1316

Relini G (1993) Mediterranean macrofouling. Oebalia 19: 103-154

Rius M, Heasman KG, McQuaid CD (2011) Long-term coexistence of non-indigenous species in aquaculture facilities. Mar Pollut Bull 62:2395-2403

Rumbold CE, Barlett TR, Gavio MA, Obenat SM (2016) Population dynamics of two invasive amphipods in the southwestern Atlantic: Monocorophium acherusicum and Ericthonius punctatus (Crustacea). Mar Biol Res 12: 268-277

Sarà G, Lo Martire M, Giacomo Buffa G, Mannino AM, Badalamenti $F$ (2007) The fouling community as an indicator of fish farming impact in Mediterranean. Aquacult Res 38:66-75

Sarà G, Porporato EM, Mangano MC, Mieszkowska N (2018a) Multiple stressors facilitate the spread of a non indigenous bivalve in the Mediterranean Sea. J Biogr 45:1090-1103

Sarà G, Mangano MC, Johnson M, Mazzola A (2018b) Integrating multiple stressors in aquaculture to build the blue growth in a changing sea. Hydrobiologia 809:5-17

Editorial responsibility: Gianluca Sarà,

Palermo, Italy
Sarà G, Gouhier TC, Brigolin D, Porporato EM and others (2018c) Predicting shifting sustainability trade-offs in marine finfish aquaculture under climate change. Glob Change Biol 24:3654-3665

Shea K, Chesson P (2002) Community ecology theory as a framework for biological invasions. Trends Ecol Evol 17: 170-176

Stachowicz JJ, Byrnes JE (2006) Species diversity, invasion success, and ecosystem functioning: disentangling the influence of resource competition, facilitation, and extrinsic factors. Mar Ecol Prog Ser 311:251-262

* Stachowicz JJ, Fried H, Osman RW, Whitlatch RB (2002) Biodiversity, invasion resistance, and marine ecosystem function: reconciling pattern and process. Ecology 83: 2575-2590

Sun Y, Wong E, Keppel E, Williamson JE, Kupriyanova EK (2017) A global invader or a complex of regionally distributed species? Clarifying the status of an invasive calcareous tubeworm Hydroides dianthus (Verrill, 1873) (Polychaeta: Serpulidae) using DNA barcoding. Mar Biol 164:28

* van Kleunen M, Dawson W, Essl F, Pergl J and others (2015) Global exchange and accumulation of non-native plants. Nature 525:100-103

*Vilà M, Espinar JL, Hejda M, Hulme PE and others (2011) Ecological impacts of invasive alien plants: a meta-analysis of their effects on species, communities and ecosystems. Ecol Lett 14:702-708

Wallentinus I, Nyberg CD (2007) Introduced marine organisms as habitat modifiers. Mar Pollut Bull 55:323-332

WWonham MJ, Carlton JT (2005) Trends in marine biological invasions at local and regional scales: the northeast Pacific Ocean as a model system. Biol Invasions 7: 369-392

Y Yurkonis KA, Meiners SJ, Wachholder BE (2005) Invasion impacts diversity through altered community dynamics. J Ecol 93:1053-1061

* Zenetos A, Çinar ME, Pancucci-Papadopoulou MA, Harmelin JG and others (2005) Annotated list of marine alien species in the Mediterranean with records of the worst invasive species. Mediterr Mar Sci 6:63-118

Zenetos A, Gofas S, Verlaque M, Çinar ME and others (2010) Alien species in the Mediterranean Sea by 2010. A contribution to the application of European Union's Marine Strategy Framework Directive (MSFD). Part I. Spatial distribution. Mediterr Mar Sci 11:381-493

* Zenetos A, Gofas S, Morri C, Rosso A and others (2012) Alien species in the Mediterranean Sea by 2012. A contribution to the application of European Union's Marine Strategy Framework Directive (MSFD). Part 2. Introduction trends and pathways. Mediterr Mar Sci 13: 328-352

Z Zenetos A, Çinar ME, Crocetta F, Golani D and others (2017) Uncertainties and validation of alien species catalogues: the Mediterranean as an example. Estuar Coast Shelf Sci 191:171-187

Zibrowius H (1971) Les espèces Méditerranéennes du genre Hydroides (Polychaeta Serpulidae). Remarques sur le prétendu polymorphisme de Hydroides uncinata. Tethys 2:691-746

Submitted: June 6, 2018; Accepted: October 31, 2018

Proofs received from author(s): January 14, 2019 